\title{
Length-based assessment of southern brown shrimp stock from trawl fisheries on the
}

\section{Amazon Continental Shelf}

\author{
A valiação do estoque do camarão rosa em pescarias dle arrasto na plataforma continental da \\ Amazônia \\ Evaluación del stock de camarón rosado en pesquerías de arrastre industrial en la plataforma \\ continental amazónica
}

Received: 06/20/2021 | Reviewed: 06/29/2021 | Accept: 07/05/2021 | Published: 07/15/2021

Ualerson Iran Peixoto
ORCID: https://orcid.org/0000-0001-7078-3424
Universidade Federal do Pará, Brazil
E-mail: ualersonpeixoto@gmail.com
Bianca Bentes
ORCID: https://orcid.org/0000-0002-4089-7970
Universidade Federal do Pará, Brazil
E-mail: biancabentes@ ufpa.br
Humber Agrelli Andrade
ORCID: https://orcid.org/0000-0002-4221-8441
Universidade Federal de Pernambuco, Brazil
E-mail: humber.andrade@ gmail.com
Victoria Judith Isaac
ORCID: https://orcid.org/0000-0002-7652-2708
Universidade Federal do Pará, Brazil
E-mail: biologiapesqueira@ @ hotmail.com

\begin{abstract}
Virtual Population Analysis (VPA) is a diagnostic tool that providing valuable input for management decisions to sustainable catches for marine fisheries. Industrial shrimp trawling produces one of the most valuable export commodities in the Brazilian fishery sector. Due to the profitability, there is pressure on government agencies to increase the number of fishing licenses. The present study used the body-length data available for the industrial southern brown shrimp trawling fleet of the Amazon Continental Shelf (ACS), Brazil, to estimate the current maximum sustainable yield and test the potential effects of increased effort on the sustainability of this fishery. The available data encompasses 13 years of onboard monitoring of shrimp trawling. The VPA was run in an Excel spreadsheet. The results indicate that the ACS shrimp stock has high fishing (F) mortality rates, although exploitation levels can be considered adequate below the MSY. An increase of up to $40 \%$ in fishery effort - including the expansion of the number of vessels - would not result in overfishing, although we would not recommend an increase in effort, as this may increase impacts on the bycatch fauna and eventual economic losses in the event of the failure of recruitment.
\end{abstract}

Keywords: Fishery management; Shrimp fishery; Mortality rate; Stock assessment.

\section{Resumo}

A Análise de População Virtual (VPA) é uma ferramenta de diagnóstico que fornece informações valiosas para decisões de gestão de capturas sustentáveis para a pesca marinha. $\mathrm{O}$ arrasto industrial de camarão produz uma das commodities de exportação mais valiosas do setor pesqueiro brasileiro. Devido à lucratividade, há pressão sobre os órgãos governamentais para aumentar o número de licenças de pesca. O presente estudo usou os dados de comprimento do corpo disponíveis para a frota industrial de arrasto de camarão negro do sul da Plataforma Continental da Amazônia (ACS), Brasil, para estimar o rendimento máximo sustentável atual e testar os efeitos potenciais do aumento do esforço na sustentabilidade desta pescaria. Os dados disponíveis abrangem 13 anos de monitoramento a bordo da pesca de arrasto de camarão. O VPA foi executado em uma planilha Excel. Os resultados indicam que o estoque de camarão ACS apresenta altas taxas de mortalidade por pesca $(\mathrm{F})$, embora os níveis de exploração possam ser considerados adequados abaixo do MSY. Um aumento de até $40 \%$ no esforço de pesca incluindo a expansão do número de embarcações - não resultaria em sobrepesca, embora não recomendamos um aumento do esforço, pois isso pode aumentar os impactos sobre a fauna de capturas acessórias e eventuais perdas econômicas em o caso de insucesso do recrutamento.

Palavras-chave: Manejo da pesca; Pesca do camarão; Taxa de mortalidade; Avaliação de estoque. 


\section{Resumen}

El Análisis de población virtual (VPA) es una herramienta de diagnóstico que proporciona información valiosa para las decisiones de gestión sostenible de las capturas para la pesca marina. La pesca de arrastre industrial de camarón produce uno de los productos de exportación más valiosos de la industria pesquera brasileña. Debido a la rentabilidad, existe presión sobre las agencias gubernamentales para que aumenten el número de licencias de pesca. El presente estudio utilizó los datos de longitud corporal disponibles para la flota de arrastre de camarón marrón del sur de la plataforma continental amazónica (ACS), Brasil, para estimar el rendimiento máximo sostenible actual y probar los efectos potenciales de un mayor esfuerzo sobre la sostenibilidad de esta pesquería. Los datos disponibles cubren 13 años de monitoreo a bordo de la pesca de arrastre de camarón. El VPA se ejecutó en una hoja de cálculo de Excel. Los resultados indican que el stock de camarón ACS tiene altas tasas de mortalidad por pesca (F), aunque los niveles de exploración pueden considerarse adecuados por debajo del RMS. Un aumento de hasta un $40 \%$ en el esfuerzo pesquero, incluida una expansión en el número de embarcaciones, no resultaría en una sobrepesca, aunque no recomendamos un aumento en el esfuerzo, ya que esto puede incrementar los impactos en la fauna de las capturas accesorias y eventuales pérdidas económicas en el caso de una contratación fallida.

Palabras clave: Ordenación pesquera; Pesca de camarón; Tasa de mortalidade; Evaluación de poblaciones.

\section{Introduction}

Worldwide, shrimp are the main type of crustacean harvested by both artisanal and industrial trawl fisheries, providing an economically valuable catch that supports many fishing communities (Blanchard et al., 2019). Although they oscillate considerably, global shrimp catches have reached record levels in recent years, due primarily to the recovery of specific stocks, as in Argentina. Despite a reduction in fishing effort, however, the stocks of shrimp of the family Peneaeidae in the Caribbean, the continental shelf of the Guianas, and the southwestern Indian Ocean have not shown signs of recovery recently (Gillet 2008; FAO 2020). Shrimp trawling is one of the least sustainable types of fisheries, given its high levels of bycatch and impact on the seabed (Isaac et al., 2009; Foster \& Vincent 2010; Pérez-Roda et al., 2019; McConnaughey et al., 2020). In general, indiscriminate pressure from fisheries reduces sustainability, and this has changed little in recent years, especially in the case of trawl fisheries, which require relatively high levels of investment and capitalization (Isaac et al., 1992).

One of the most productive penaeid fishing grounds in the world is located within the North Brazil Shelf Large Marine Ecosystem, which extends from Brazil to Venezuela, comprising six countries and an area of 223,000 km² (IBAMA 1994; FAO 2017; Isaac \& Ferrari 2017). The fishing grounds of northern Brazil extend from the mouth of the Parnaíba River, in Piauí state, to the mouth of the Oiapoque River, in Amapá state (Aragão et al., 2015a). Most of the trawling effort is concentrated on the Amazon Continental Shelf (ACS), off the states of Pará and Amapá, within an area of 112,699 km² (Fig. 1). The target is the southern brown shrimp, which includes at least three species - Penaeus brasiliensis, Penaeus subtilis, and the recently-described Penaeus isabelae (Aragão et al., 2015a; Tavares \& Gusmão 2016), although. Estimates show that almost all catches are made up of P. subtilis (Isaac et al., 1992; MPA 2011; Aragão et al., 2015a).

The shrimp trawlers are primarily industrial steel vessels, which operate double-rig bottom trawls, with a mean length of 22 meters, onboard icing systems, and a holding capacity of approximately 20 tonnes. These vessels undertake four to six trips per year, with a mean trip duration of 45 days, with the majority of the catch being exported (Isaac et al., 1992; Frédou et al., 2009; Aragão et al., 2015a). The number of trawlers increased rapidly up to the mid-1980s, with a fleet of 287 vessels in 1985 (FAO 2017). However, this number has decreased gradually to the present day, and in 2013, only 60 vessels were operational. Since 2017, a maximum of 101 shrimp trawling licenses has been issued by the Brazilian authorities (Brasil 2017; FAO 2017).

The industrial southern brown shrimp trawler fleet of the ACS is an expensive operation, which requires a high level of investment from the vessel owners for each trip. The mean annual operating cost of a vessel in 2003 was approximately US\$148,852.72, while mean revenues were around US\$195,450.09, with an annual profit of approximately US\$45,597.34 
(Carvalho et al., 2003). In this same year, total exports reached US\$37.9 million, although they subsequently declined to only US\$6.9 million in 2011 (Aragão et al., 2015b). Although exports have declined, the stock assessments of Isaac et al. (1992), Ehrhardt et al. (1999), and Aragão et al. (2015b) found that stocks were at sustainable levels.

As they are $r$-selected, shrimp do not appear to be affected too adversely by an increase in capture effort, as their stocks can recover quickly (Garcia 1988). However, an increase in effort may lead to an overcapitalized fleet, resulting in economic losses (Di Cintio and Moreno 2017). The principal problem with shrimp stocks is the occurrence of recruitment failures provoked by environmental changes or extreme climate events (Garcia 1996). These failures result in poor harvests, leading to the bankruptcy of the shrimping fleet and the industrial plants that process the catches. Understanding how the current levels of exploitation are affecting the shrimp stocks and the current support capacity will be essential to avoid future problems of overcapitalization in this fishery.

The classical assessment models based on the evaluation of target species are useful for the analysis of the sustainability of fishery stocks (Hilborn et al., 2020). Quantitative models are a fundamental approach to population assessment and are often the only option for the planning of the sustainability of fisheries in the case of data-poor species (Pilling et al., 2008). Estimating reference points from the harvested stocks is necessary to ensure adequate levels of exploitation and abundance (Martell \& Froese 2013). Where data are limited, body length-based methods are frequently the only way to assess the status of a stock as input for the decision-making process by stakeholders and policy makers (Csirke et al., 1987).

Like many Brazilian fisheries, the Amazonian shrimp trawling fleet is a data-poor system given that only a time series of catch, size composition, and effort data are available, with numerous sample gaps. In this case, classical body length-based assessment models, such as Virtual Population Analysis (VPA), which estimate abundance and mortality rates for catch-at-age or length-based data, provide a useful diagnostic option (Quin \& Deriso 1999; Pauly 1984). The VPA is a valuable tool for the assessment of data-limited tropical fisheries, and it has been widely-used because the necessary input data are relatively easy to collect (Christensen 1996; Gulland \& Rosemberg 1992). While relatively simple to apply, the body length-based VPA is a robust tool, providing valuable information for stakeholders, in particular, estimates of the Maximum Sustainable Yield, MSY (Jones 1984).

Given its profitability, there is intense pressure from the industry to increase the number of shrimp trawling licenses issued annually, which would increase fishing effort and pressures on the stocks. Given this, the present study used the available body length-based data obtained from the industrial southern brown shrimp trawling fleet that operates on the ACS to determine the current status of the stock and the potential effects of increased effort on the sustainability of this shrimp fishery. The study provides important insights into the optimal levels of effort for one of the world's most important and productive shrimping grounds, which should contribute to the implementation of effective fishery management measures on the northern coast of Brazil. This study also provides important methodological insights for future studies in stock assessment.

\section{Methodology}

\subsection{Study area}

The fishing grounds of the southern brown shrimp on the Amazon Continental Shelf (ACS) of northern Brazil extend from $4^{\circ} 16^{\prime} \mathrm{N}$ to $3^{\circ} \mathrm{S}$ (Ekau \& Knoppers 1999). However, operations are concentrated off the coasts of the states of Pará and Amapá (Figure 1). 
Figure 1: The Amazon Continental Shelf, northern Brazil, showing the principal fishing grounds exploited by the shrimp trawling fleet. (Peixoto et al., submitted).

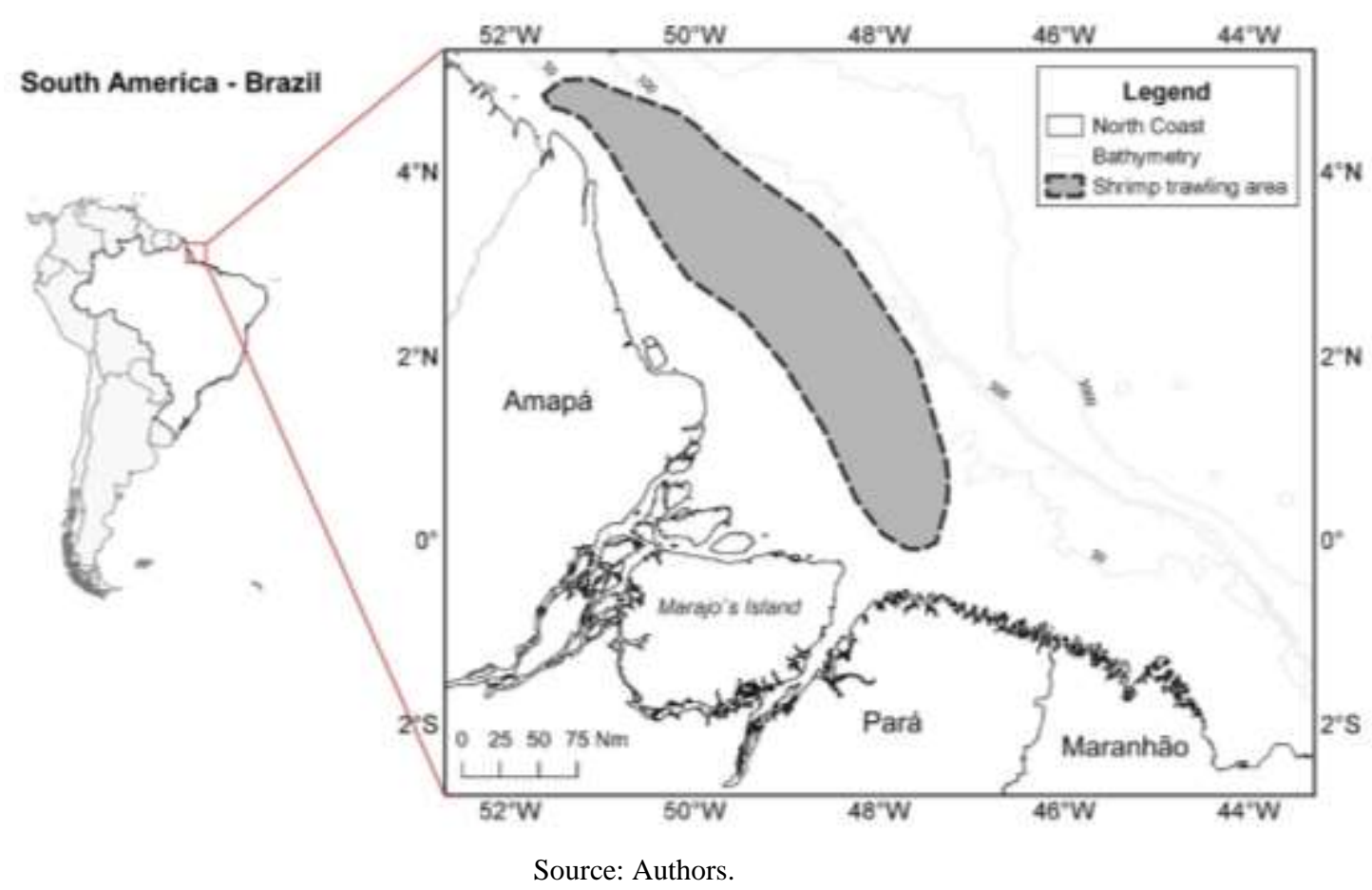

The shrimping fleet begins to operate on the ACS in February, after the end of the closed season, continuing up to December (Brasil 2018). The vessels move northward from fishing grounds close to the mouths of the Amazon and Pará rivers toward the border between Brazil and French Guiana over the course of the year, following the shrimp migration pattern on the ACS (Peixoto, 2020).

This region has a humid tropical climate with an intense rainy season during the first half of the year, and a dry season during the second half of the year, when rainfall declines considerably. This rainfall pattern influences the hydrological cycle of the Amazon region, with fluvial discharge declining during the dry season and then increasing again during the rainy period (Barthem \& Schwassmann 1994). The region is considered to be highly productive (> $300 \mathrm{gCm}^{-2} \mathrm{yr}^{-1}$ ), due primarily to the terrestrial input. During the rainy season, the increase in the discharge of the Amazon River reinforces the outflow of the river, which pushes back the seawater and forms a unique ecosystem known as the "Amazon plume" which is responsible for the transport of suspended matter, sediments, and nutrients, and changes in salinity, well into the Atlantic Ocean (Isaac \& Ferrari 2017).

The coastline is dominated by macrotidal shifts, and the marine environment is influenced primarily by North Brazil Current. Due to turbidity of the water, primary productivity is limited by the reduced penetration of sunlight in the shallow water and a lack of nutrients in the open waters, being highest in the transition area between these two types of water. The topography of the region is dominated by gently-sloping bottoms, and a muddy and sandy seabed interspersed with some areas of gravel and calcareous algae (Nittrouer et al., 1986; Nittrouer \& De Master 1996; Heileman 2008).

\subsection{Data collection}

Individual samples of southern brown shrimp, P. subtilis, were taken onboard industrial trawlers during fishing operations, in 2000-2007, 2010 and 2014-2017, with a total of 217,718 shrimps being measured from 1,281 trawls during the 
13 years of the study. A random subsample of individuals was obtained during each trawling operation, with the total length of each shrimp being measured in centimeters. As there were some gaps in the sampling, the data were grouped to cover all the months of the year and simulate a population in equilibrium, without the influence of variation in recruitment. By doing this, all the months had samples except January, which is the closed season.

\subsection{Data analysis}

A body length-based Virtual Population Analysis (VPA) was applied to the monthly body-length frequency data of the pooled sexes, with a 1-cm class interval. The total length of the shrimp varied from $2.5 \mathrm{~cm}$ to $23.5 \mathrm{~cm}$. Jones \& Zalinge's (1981) length-based cohort analysis was applied to these data. This routine uses the same approach as the VPA structured by age but is adapted to accommodate length frequencies according to the back-transformation of the von Bertalanffy model (Lassen \& Medley 2001). The VPA inputs are shown in Table 1.

Table 1: Estimated parameters of the southern brown shrimp, Penaeus subtilis, caught on the Amazon Continental Shelf.

\begin{tabular}{lll}
\hline Parameter & Value & Source \\
\hline$a$ (Length-weight relationship) & $0.0057\left(\mathrm{Kg}_{\mathrm{cm}}\right)$ & Ferreira (2012) \\
$b$ (Length-weight relationship) & 3.09 & Ferreira (2012) \\
M (Natural mortality) & 2.26 year $^{-1}$ & Ferreira (2012) \\
L (Asymptotic length) & $25 \mathrm{~cm}$ & Present study \\
K (Growth rate) & 0.83 year $^{-1}$ & Ferreira (2012) \\
\hline
\end{tabular}

Source: Authors.

The initial step is to estimate the terminal population ( $\mathrm{Nt}$ ), or the number of individuals in the largest length class, using the equation:

\section{$\mathrm{Nt}=\mathrm{Ct} *(\mathrm{M}+\mathrm{Ft}) / \mathrm{Ft}$}

where $\mathrm{C}_{\mathrm{t}}=$ the terminal catch (i.e., the catch of the largest length), $\mathrm{M}=$ the constant natural mortality, and $\mathrm{F}_{\mathrm{t}}=$ the terminal fishing mortality.

Starting from $\mathrm{Nt}$, we estimated successive values of $\mathrm{F}$, by iteratively solving:

$$
C i=N i+\Delta t *\left(\frac{F i}{Z i}\right) *(\exp (Z i * \Delta t i)-1)
$$

where $\Delta \mathrm{t}_{\mathrm{i}}=\left(\mathrm{t}_{\mathrm{i}+1}-\mathrm{t}_{\mathrm{i}}\right), t i=t 0-\left(\frac{1}{k}\right) * \ln \left(1-\left(\frac{L i}{L}\right), \mathrm{Z}=\right.$ total mortality, and $\mathrm{F}=$ the fishing mortality.

The population sizes $(\mathrm{Ni})$ were calculated by:

$$
N \hat{i}=N \hat{i}+\Delta t * \exp (Z \hat{i})
$$

These two equations were applied alternatively until the population sizes and fishing mortality for all successive length groups were computed (Gayanillo et al., 2005). We ran the VPA simulating an increase of the fleet by $40 \%$ (154 vessels), 30\% (143 vessels), and 20\% (132 vessels), by increasing the F values. As recruitment cannot be predicted in a simulation, it was assumed to be constant. 
The VPAs were run by estimating the biomass (tonnes), yield (tonnes), total mortality (Z), natural mortality (M), fishing mortality (F), and exploitation ratio (E) using the following equation (Jones 1984):

$$
N L 2=N L 1 *(X L i, L 2+C L 1, L 2) * X L 1, L 2
$$

where NL1 and NL2 are the numbers of individuals in the initial (L1) and final (L2) class intervals, CL1, L2 is the number of individuals in each class interval, and XL1, L2 is the natural mortality factor for each class interval.

The natural mortality (M) was calculated for each class interval by:

$$
X_{L 1, L 2}=\left(\frac{L \infty-L 1}{L \infty-L 2}\right)^{M / 2 F}
$$

While the exploitation rate $(\mathrm{E})$ and the fishing mortality $(\mathrm{F})$ were calculated per class interval by:

$$
\begin{gathered}
E=\left(\frac{C_{L 1, L 2}}{N_{L 1}-N_{L 2}}{ }^{\prime}\right. \\
F=\left(\frac{\frac{F}{Z_{L i, L 2}}}{1-\frac{F}{Z_{L 1, L 2}}}\right)
\end{gathered}
$$

Total mortality $(Z)$ for each class interval was calculated using:

$$
Z=\left(\frac{M_{L 1, L 2}}{1-F / Z_{L 1, L 2}}\right.
$$

The Maximum Sustainable Yield (MSY) was estimated using Cadima's formula for exploited stocks (Sparre \& Venema 1998):

$$
M S Y=0.5 *(Y+M b)
$$

where $\mathrm{B}=$ total biomass, $\mathrm{Y}=$ annual yield, and $\mathrm{M}=$ natural mortality rate.

The yield (Y) was estimated per length class using the following expression:

$$
Y=\Sigma W_{L 1, L 2} * C_{L 1, L i}
$$

where $\mathrm{W}=$ the weight, and $\mathrm{C}=$ the catch, between two successive length classes. The total biomass (B) was estimated by:

$$
B=\Sigma \frac{N_{L 1}-N_{L 2}}{Z_{L 1, L 2}} * \text { meanbodyweight }
$$

The body weight for each class interval was calculated as:

$$
\text { Bodyweight }=a *\left[\frac{L 1+L 2}{2}\right]_{L}
$$

where $a$ is the intercept and $b$ is the slope of the length-weight relationship.

The annual shrimp production statistics were used to verify the catch trends between 1980 and 2010 (Aragão, 2012). All the analyses were run in a Microsoft Excel spreadsheet. 


\section{Results}

\subsection{Size structure composition}

The catches were composed of southern brown shrimp, $P$. subtilis, with total lengths varying from $2.5 \mathrm{~cm}$ to $23.5 \mathrm{~cm}$ (Figure 2). The most frequent size class was $12.5 \mathrm{~cm}$, while $82.65 \%$ of the individuals captured had a total length of between $10.5 \mathrm{~cm}$ and $15.5 \mathrm{~cm}$.

Figure 2: Frequency distribution of the total length classes of southern brown shrimp, Penaeus subtilis, caught on the Amazon Continental Shelf.

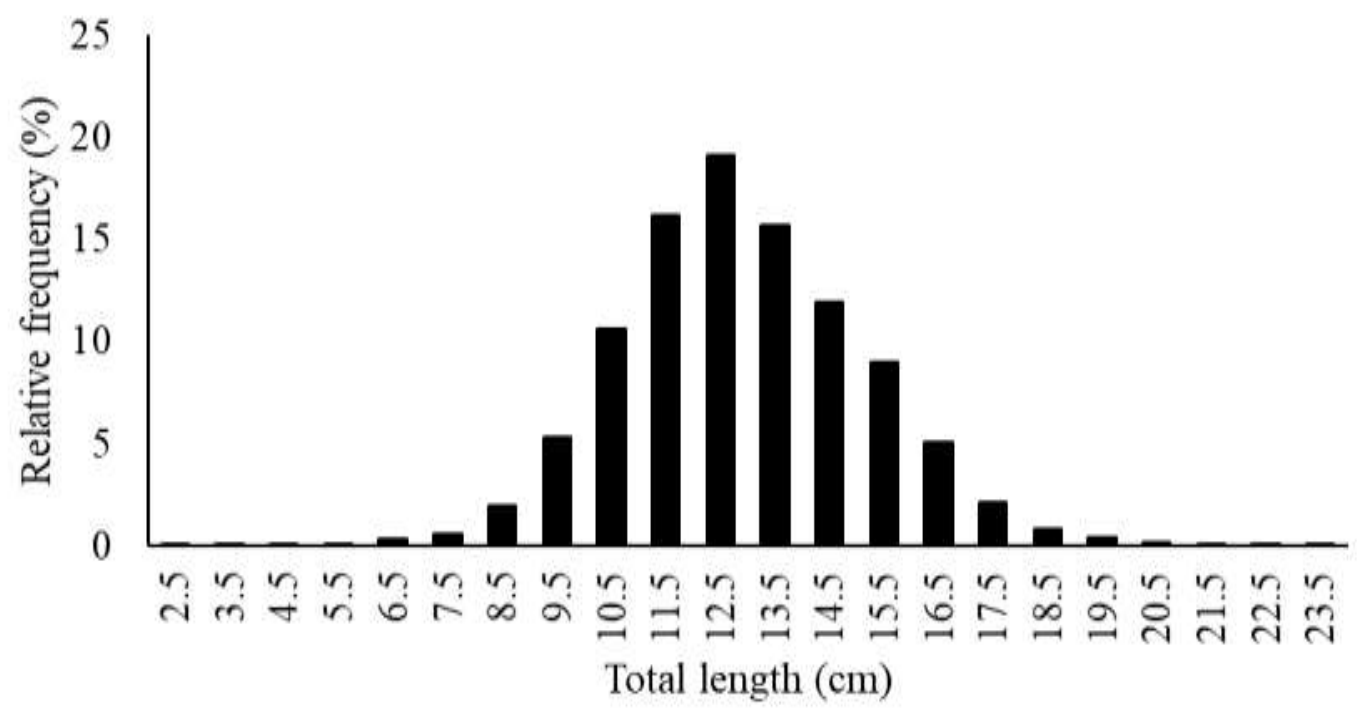

Source: Authors.

\subsection{Virtual Population Analysis (VPA)}

Fishing mortality $(F)$ affects individuals of $8.5-23.5 \mathrm{~cm}$ in length, with fast-increasing $\mathrm{F}$ values from $11.5 \mathrm{~cm}$ to the highest values in the $15.5 \mathrm{~cm}$ and $16.5 \mathrm{~cm}$ length classes (Figure 3). The mean number of recruits into the stock was calculated as 39,132 million individuals. 
Figure 3: Results of length-based Virtual Population Analysis for southern brown shrimp caught off the Amazon Continental Shelf.

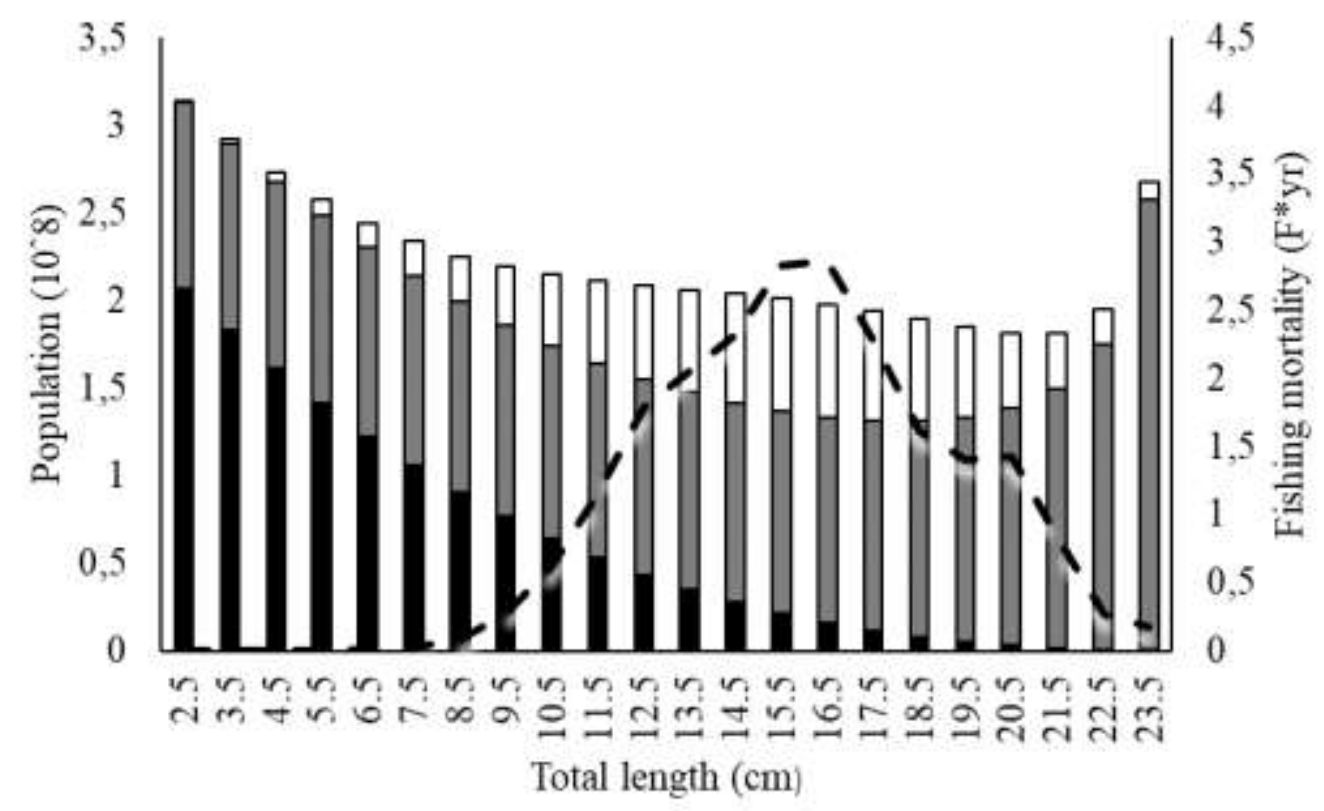

Survivors (ind.)

$\square$ Nat. Losses (ind.)

$\square$ Catches (tonnes) $-\mathrm{F}$

\section{Source: Authors.}

The results of the simulated increase of $20 \%, 30 \%$, and $40 \%$ in the number of vessels operating in the study area (Figure 4) indicated a shift the fishing mortality curve, with a slight increase in the participation of specimens in the size classes of between $12.5 \mathrm{~cm}$ and $20.5 \mathrm{~cm}$. 
Figure 4: Results of the VPAs following a simulated increase in fishing effort (F) of (a) 20\%, (b) $30 \%$, and (c) $40 \%$ in the southern brown shrimp caught on the Amazon Continental Shelf.
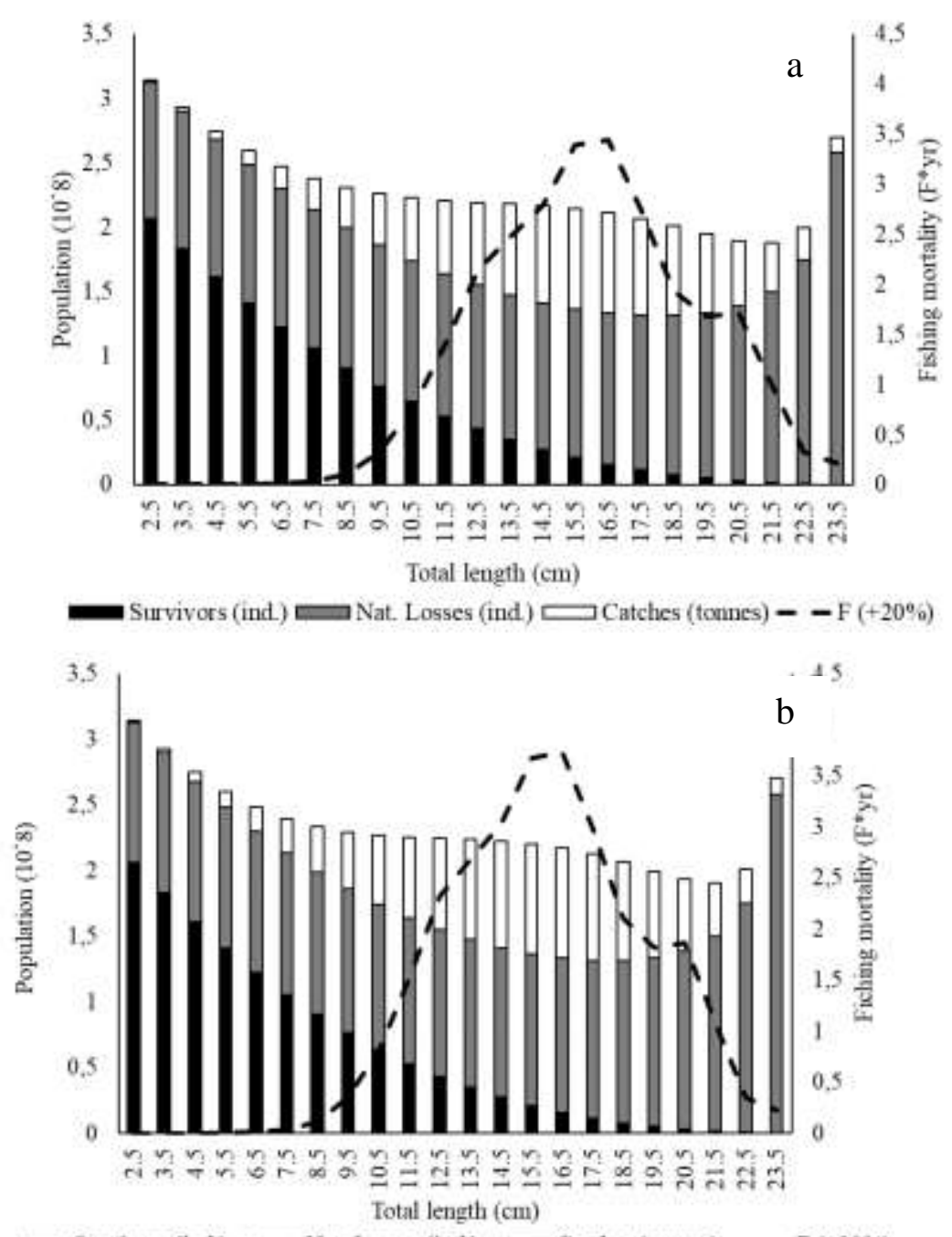

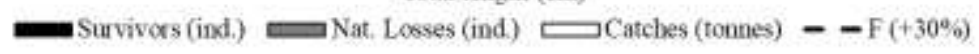

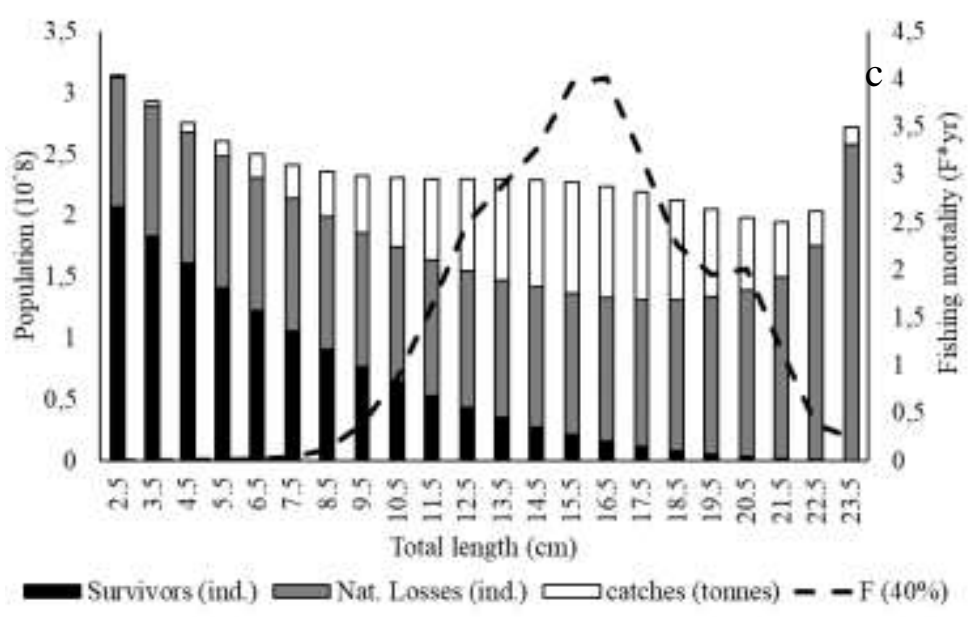

Source: Authors. 


\subsection{Maximum Sustainable Yield}

The instantaneous biomass in the sea for the current $\mathrm{F}$ and $\mathrm{M}$ conditions of the ACS was estimated to be 2,959 tonnes (Table 1). The estimated average yield was 3,787 tonnes.year-1 ${ }^{-1}$ The Maximum Sustainable Yield (MSY) was estimated to be 5,235.18 tonnes.year ${ }^{-1}$. Oscillations in annual production were observed over time, and a negative trend in catches was observed after 1987-1988 when the yield exceeded the estimated MSY (Figure 5).

Table 2: Biomass, yield, and Maximum Sustainable Yield (MSY) by length classes for southern brown shrimp, P. subtilis, caught off the Amazon Continental Shelf.

\begin{tabular}{|c|c|c|c|c|c|c|c|c|}
\hline Total length $(\mathrm{cm})$ & Catch (ind.) & XL1, L2 & E & $\mathrm{F}$ & $\mathrm{Z}$ & Biomass/t & Body weight/t & Yield/t \\
\hline 2.5 & 8 & 1.0625866 & $4 \mathrm{E}-05$ & $9.514 \mathrm{E}-05$ & 2.2671 & 8.19 & 0.10 & 0.78 \\
\hline 3.5 & 10 & 1.0655921 & $6 \mathrm{E}-05$ & 0.0001287 & 2.2671 & 21.46 & 0.28 & 2.76 \\
\hline 4.5 & 103 & 1.0689009 & 0.0006 & 0.0014392 & 2.2684 & 43.04 & 0.60 & 61.94 \\
\hline 5.5 & 332 & 1.0725611 & 0.0022 & 0.0050593 & 2.2721 & 73.47 & 1.12 & 371.72 \\
\hline 6.5 & 825 & 1.0766319 & 0.006 & 0.0137797 & 2.2808 & 112.46 & 1.88 & $1,549.70$ \\
\hline 7.5 & 1,399 & 1.0811866 & 0.0112 & 0.0257604 & 2.2928 & 158.91 & 2.93 & $4,093.62$ \\
\hline 8.5 & 4,259 & 1.0863167 & 0.037 & 0.0871768 & 2.3542 & 210.65 & 4.31 & $18,363.89$ \\
\hline 9.5 & 11,601 & 1.0921387 & 0.1058 & 0.2681284 & 2.5351 & 263.29 & 6.09 & $70,594.58$ \\
\hline 10.5 & 23,114 & 1.0988025 & 0.2151 & 0.6211309 & 2.8881 & 308.74 & 8.30 & $191,770.46$ \\
\hline 11.5 & 35,310 & 1.1065051 & 0.3381 & 1.1579276 & 3.4249 & 335.35 & 11.00 & $388,309.54$ \\
\hline 12.5 & 41,620 & 1.1155096 & 0.4403 & 1.7833396 & 4.0503 & 332.29 & 14.24 & $592,578.66$ \\
\hline 13.5 & 34,258 & 1.1261764 & 0.4754 & 2.0546437 & 4.3216 & 301.30 & 18.07 & $619,059.90$ \\
\hline 14.5 & 26,106 & 1.1390124 & 0.5067 & 2.3287292 & 4.5957 & 252.77 & 22.55 & $588,621.93$ \\
\hline 15.5 & 19,553 & 1.1547535 & 0.5546 & 2.8232437 & 5.0902 & 191.99 & 27.72 & $542,027.92$ \\
\hline 16.5 & 11,135 & 1.174511 & 0.5585 & 2.8679883 & 5.135 & 130.62 & 33.64 & $374,627.67$ \\
\hline 17.5 & 4,763 & 1.2000447 & 0.5018 & 2.2830942 & 4.5501 & 84.22 & 40.37 & $192,283.27$ \\
\hline 18.5 & 1,853 & 1.2343171 & 0.4164 & 1.6175453 & 3.8845 & 54.93 & 47.95 & $88,856.25$ \\
\hline 19.5 & 880 & 1.2827289 & 0.3815 & 1.3985592 & 3.6656 & 35.52 & 56.45 & $49,671.90$ \\
\hline 20.5 & 451 & 1.3562707 & 0.387 & 1.4314531 & 3.6985 & 20.76 & 65.90 & $29,721.98$ \\
\hline 21.5 & 117 & 1.4812357 & 0.2672 & 0.8266339 & 3.0936 & 10.81 & 76.38 & $8,936.26$ \\
\hline 22.5 & 17 & 1.7397276 & 0.1075 & 0.2730705 & 2.5401 & 5.47 & 87.93 & $1,494.77$ \\
\hline 23.5 & 4 & 2.5769466 & 0.0722 & 0.176307 & 2.4433 & 2.28 & 100.61 & 402.42 \\
\hline \multicolumn{8}{|c|}{$2958.52 \mathrm{t}$} & $3763.41 \mathrm{t}$ \\
\hline MSY & $5,235.18 \mathrm{t}$ & & & & & & & \\
\hline
\end{tabular}


Figure 5: Annual shrimp catches from the Amazon Continental Shelf, according to the official statistics. The dashed line indicates the Maximum Sustainable Yield (MSY = 5,235 tonnes).

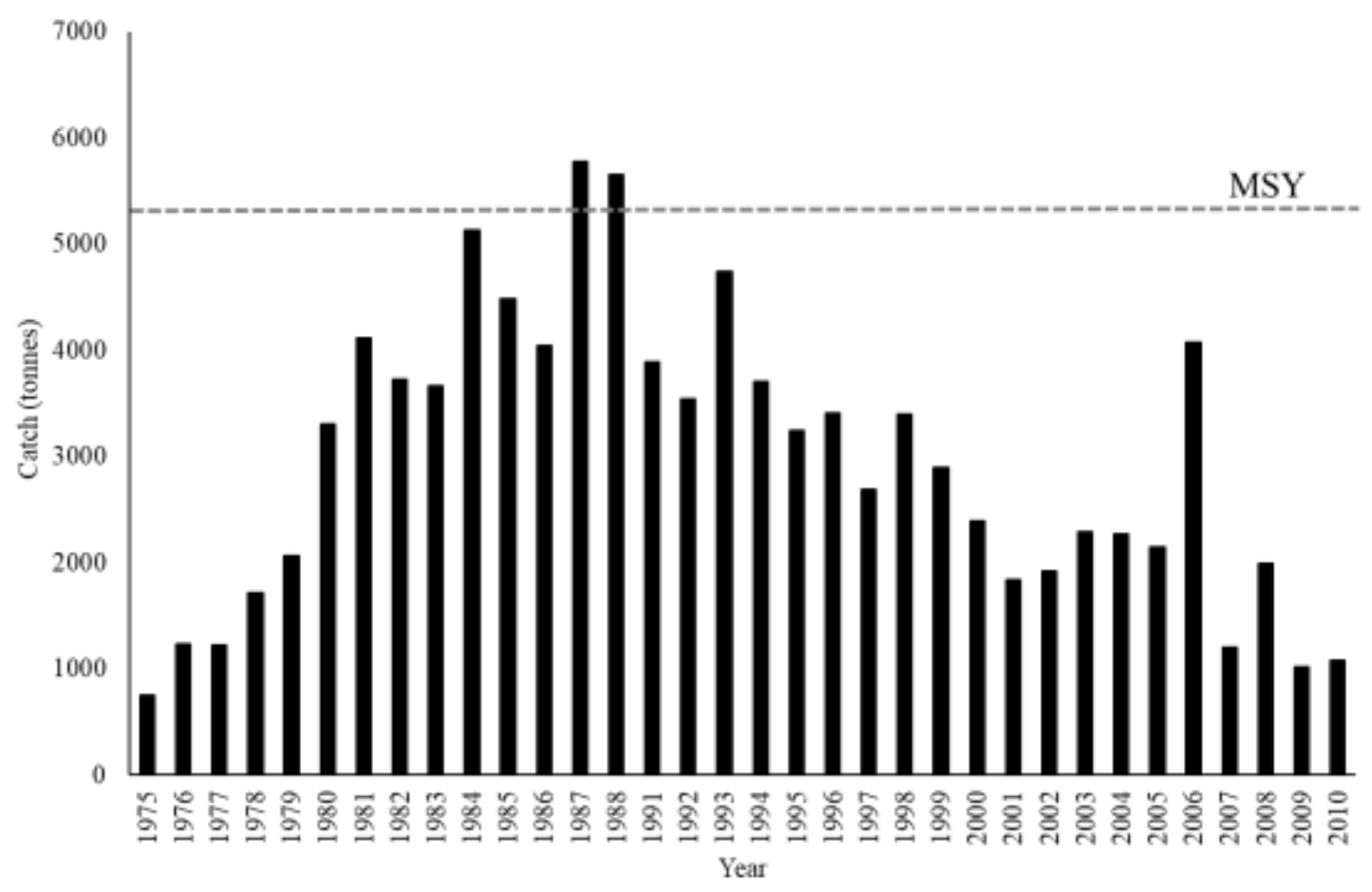

Source: Authors.

\section{Discussion}

While shrimp is one of the most valuable fishery resources of northern Brazil, it is also one of the least sustainable (Isaac et al., 1992, 2009). Despite the importance of the industrial shrimp trawling fleet of the Amazon Continental Shelf (ACS), data on its catches are both scarce and difficult to obtain, and are often inaccessible, as well as being dominated by discontinuous samples (Peixoto et al., 2020 submitted). Official Brazilian fishery statistics on total shrimp production is available only up to 2007 (IBAMA 2007). Data on the size composition of catches depend on the participation of onboard observers and government investment (Isaac et al., 1992), and are thus collected irregularly. More systematic monitoring was initiated in the early 2000s, but unfortunately, it has been suspended in recent years. The present study compiled all the available data from historical sources to analyze the productivity of the Amazonian shrimp fisheries in order to assess fishing pressure and model future scenarios based on changes in fishing effort. These simulations resulted in the modification of the size composition of the shrimp population.

The VPA approach is widely used for the assessment of stocks of data-poor marine fisheries, providing input for management decisions, but has rarely been used in Brazil (Scarnecchia et al., 2014). This approach is a valuable tool, which can provide reliable estimates of current fishing intensity, as well as modeling varying levels of fishing effort, which provides important insights for the development of management measures by stakeholders (Jones a\& Van Zalingee 1981; Jones 1984; Lassen \& Medley 2001). The VPA is a useful method for the assessment of fishery impacts given its reduced data requirements (Pauly 1984).

The VPA takes a "backward solution" approach based on historical, cohort-based abundance data on a stock that is assumed to be homogeneous (MacCall 1986). Although many environmental variables affect M rates, most of the models assume stable natural mortality (Vetter 1988). In the present case, the assumptions on natural mortality, growth parameters, and the characteristics of the catch in relation to the length distribution of the population were assumed to be in equilibrium to 
apply the VPA. If these assumptions are true, the length-based cohort analysis will produce reasonably reliable estimates of abundance and fishing mortality by length class (Jones \& Van Zalinge 1981; Jones 1984)

The predictive method of Jones (1982) used in the present study can only be applied for the prediction of yields once a new equilibrium has been established. The method assumes that the age structure of the population is stable and that there growth model is deterministic. This means that the growth parameters are constant both throughout the year and from year to year, and that differences in ages are explained only by the differences in the length of the individuals. To resolve these limitations in the present study, the data from different years were pooled, thus simulating a balanced scenario, and compensating for the differences among years in both recruitment and the abundance of each class, which support the application of a steady-state model (Wetherall et al., 1987)

The market value of shrimp is proportion to their size. In the present, the majority of the individuals harvested were in body length classes $11.5 \mathrm{~cm}$ and $12.5 \mathrm{~cm}$, which is below the estimated size at first maturity, which is $12.65 \mathrm{~cm}$ (Cintra et al., 2004). However, the fishing mortality rate (F) was highest in the $15.5 \mathrm{~cm}$ and $16.5 \mathrm{~cm}$ classes, given that older specimens are more susceptible to capture in the trawl nets (Sparre \& Venema 1997). The intensity of fishing may also be determined by intrinsic factors, such as the migration patterns of the shrimp populations, and extrinsic factors, in particular, fluctuations in the international markets and the price of shrimp of different sizes (Garcia 1988; Peixoto et al., 2020).

Most of the individuals in the 11.5-12.5 cm classes are caught around the turn of the year at depths of up to 60 meters in the shrimping grounds south of $2^{\circ} \mathrm{N}$. By contrast, large individuals $(15.5-16.5 \mathrm{~cm}$ classes) are harvested primarily in the second half of the year, at depths of over 60 meters in shrimping grounds north of $2^{\circ} \mathrm{N}$ (Martins et al., 2015; Peixoto et al., 2020), which are more distant from the principal landing port, at the city of Belém, in the eastern Amazon estuary (Figure 1). Natural mortality has an important effect on the size classes, also impacting the abundance of large individuals. However, the shrimp catches in Brazilian North coast follow an economic trend, based on the exploitation of different sizes as a way to supply several markets. Given this, one potential fishery strategy would combine a number of factors, such as the distance of the shrimping ground, the abundance of shrimp, and the size of the individuals to optimize the economic perspective of the trips.

Determining the most relevant reference parameters is a fundamental question in fishery management. The Maximum Sustainable Yield (MSY) is a simple and clear concept that defines the optimum harvest that will guarantee the sustainability of stocks over the long term, and has thus been adopted by many international bodies as a reference point for fishery management (Thorpr 2019). Even though the catches of P. subtilis exceeded the MSY of the ACS in 1987 and 1988, the total catches in the most recent years of the available data were lower than the MSY, and as effort has not increased in the meantime, it seems reasonable to assume that the stock is not overexploited (FAO 2017). Isaac et al. (1992), Ehrhardt et al. (1999), and Aragão et al. (2015b) all reached similar conclusions on the southern brown shrimp stocks of the ACS, based on alternative data and assessments tools.

The simulations run in the present study indicated that fishing effort is not the principal factors determining shrimp stock levels on the ACS. The VPA simulations indicated that, while mortality would increase in a number of size classes resulting from expanding yields, an increase in effort by up to $40 \%$ would not expose the stock to any real risk of collapse. As classical $r$-selected organisms, shrimp have early maturation, continuous spawning, and high rates of natural mortality and growth (Adams 1980; Garcia 1988). Fisheries that target more $r$-selected species tend to be more productive at high levels of F. These fisheries should recover quickly from overfishing, even at small population sizes, and seems to be less sensitive, overall, to changes in fishing effort (Pianka 1974; Garcia 1988).

Even so, shrimp have a complex life cycle that may be sensitive to environmental factors (Sanz et al., 2016). During the early life stages, when they inhabit shallow estuaries and inshore waters, shrimp suffer high natural mortality rates (M) due 
to intense predation and density-dependence processes. Shrimp recruitment may also be affected negatively by changes in the density of aquatic and coastal vegetation, salinity, and water temperatures, as well as extreme climate events that provoke major changes in yearly rainfall and river runoff (Pauly \& Ingles 1986; Dall et al., 1990; Pérez-Castañeda \& Defeo 2002; Pérez-Castañeda \& Defeo 2005; Baker et al., 2014; Mace \& Rozas 2015, Sanz et al., 2016). These factors may become increasingly relevant in the context of ongoing global climate change.

The effects of increasing fishing effort on the adults may thus be tolerable under normal conditions, but can become dramatic in extreme environmental conditions. Even at acceptable levels of exploitation, then, if the effort is excessive, the shrimping fleet may be driven to bankruptcy in years when recruitment fails, given that the catches will not compensate for the high costs of operating the vessels (Garcia 1996; Carvalho et al., 2003). Even if the stocks recover quickly in the year following recruitment failure, the economic impacts on this sector may persist. In fact, a slump in profitability in the late 1990s led to the exclusion of a large number of vessels from the fleet and the bankruptcy of shrimp packing plants in Belém (Bentes et al., in press).

From the early 1970s, the number of vessels in the ACS shrimping fleet increased rapidly to a total of 287 vessels by 1985, which exceeded the legal limit of 250 licensed vessels (Brazil 1980). These official statistics do not include an unknown, but probably a considerable number of shrimping vessels of under $18 \mathrm{~m}$ in length that operate irregularly (Isaac et al., 1992). In the subsequent years, while the number of vessels and the duration of fishing trips both decreased, catches increased, reaching their highest levels in 1987 and 1988 (Aragão et al., 2015a). Since this peak, however, catches have oscillated, but have clearly declined, in general, as has the number of vessels.

The globalization of the shrimp market has probably led to the overcapitalization of this fishery sector, as the value of the shrimp has declined and fuel prices have increased progressively (Blanchard et al., 2019). In this scenario, while investments by the vessel owners may have been increasing, profits have declined, which would account for the dwindling number of vessels and, consequently, the negative trend in the size of the catches. In 1998, the number of active vessels was 135, decreasing to 60 in 2013 (FAO 2017), probably because shrimping is no longer as profitable as it was when the fleet was established, in the 1970s. The available evidence this indicates that, even though the MSY was not exceeded, the shrimping industry adapted by reducing the number of vessels to improve profitability (Chemonics 2002). In fact, the Brazilian government only imposed the limit of 101 licenses after the size of the fleet had declined naturally.

It is also important to note here that shrimp are detritivores, whose ecology is linked to rainfall levels and the quality of the muddy substrates (Dall et al., 1990; Nagelkerken et al., 2008). The Amazon River discharges enormous quantities of terrigenous nutrients into the local coastal waters, creating a rich muddy environment (Isaac \& Ferrari 2017), although ongoing climate change is predicted to create drier conditions, which may alter this scenario (Betts et al., 2008). In fact, alterations in the characteristics and productivity of the muddy coastal substrates may affect the local shrimp stocks and provoke recruitment failures. In this scenario, increasing fishing effort to compensate for over-capitalization and avoid bankruptcy would not be recommendable.

One other important question is the impact of increased effort on bycatch mortality, which was not considered in the analyses presented here. Shrimp trawls are responsible for significant impacts on the marine environment. Brazilian marine fisheries produce more than 361,000 tons.year ${ }^{-1}$ of bycatch, in particular by the trawlers operating along the coast and on the continental shelf. In northern Brazil, it is estimated that $8.9 \mathrm{~kg}$ of bycatch is taken for each kilogram of shrimp caught (Connoly 1992; Davies et al., 2009). Shrimp trawls are extremely non-selective and capture enormous quantities of non-target species, such as crustaceans, fish, and other demersal and benthic organisms, including threatened, endangered, and protected species (Bentes et al., 2019). Most of this bycatch has no economic value and is discarded back into the sea, generally dead, with only a few commercially-valuable fish species being retained for eventual sale (Isaac \& Braga 1999; Stobutzki et al., 
2001; Stiles et al., 2010). Only a few studies have assessed the impacts this non-target fauna of the ACS (Damasceno \& Evangelista 1991; Isaac \& Braga 1999; Paiva et al., 2009; Maia et al., 2016; Marceniuk et al., 2019).

In this context, it would seem reasonable to conclude that an increase in the number of shrimping vessels would result in the growth in bycatch mortality, as well as the expansion of the bottom trawler footprint on the seabed of the ACS. The ecological impacts of this bycatch have been poorly studied, and no continuous data time series is available. Given this, the simultaneous monitoring of the bycatch, together with the shrimp catches, should be a priority for the government, in addition to more systematic research into potential technological solutions that reduce or avoid bycatch, without any significant decrease in the shrimp catches.

Stock assessment methods typically use mortality rates to estimate the support capacity of the population in relation to fishing effort. In most of the world's managed fisheries, the effort is controlled as a means of reducing mortality and attaining a sustainable MSY (Ricker 1975). Even in the case of extremely short-lived organisms, such as shrimp, the control of effort is the measure most recommended to avoid extreme fishing pressure and over-capitalization (Garcia 1996). Excessive investment and effort are, in fact, the principal problems facing most industrial fisheries worldwide (Bowen and Hancock, 1985). Even so, an increase in the current effort should not be encouraged actively, given that occasional failures in recruitment are expected in some years, which are predicted to cause bankruptcies in part or all of the trawling fleet. Fishing effort should nevertheless increase naturally over time, as technology and fishing power evolve. Even if the number of vessels is limited, the active units will increase their fishing power naturally over time through improvements in the trawling equipment and naval technology, which will have knock-on effects for capture rates and total effort.

\section{Conclusions}

The present study aimed to produce reliable estimates of the abundance of stocks and fishing effort, to be used as input for the development of management strategies for the southern brown shrimp fishery of the Amazon Continental Shelf (ACS). The VPA model indicated that the shrimp stock of the ACS is exploited at moderate levels and that it would sustain an increased fishing effort, which could include the expansion of the 101 vessels licensed by the government for this activity in the region. The impacts of this fishery on the ecosystem, in particular from its high volume of bycatch, should be more investigated more systematically in the future through continuous monitoring and, eventually, the implementation of measures that mitigate the impact of bycatch. The ACS shrimp appears to be regulated primarily by economic factors, which would account for the decline in catches observed since 1988.

\section{Acknowledgments}

We are grateful to Centro Nacional de Pesquisa e Conservação da Biodiversidade Marinha do Norte (CEPNOR) and Instituto Chico Mendes de Conservação da Biodiversidade (ICMBio), for providing the shrimp monitoring data, which were fundamental to the present study. We are also grateful to project Rede cooperativa multidisciplinar para subsidiar o manejo da pesca dos estoques de camarões da região Norte e Nordeste do Brasil com foco ecossistêmico Processo 445766/2015-8 MCTI/MPA/CNPq. The Conselho Nacional de Desenvolvimento Científico e Tecnológico (CNPq) for provided Ualerson I. Peixoto a graduate scholarship and Victoria J. Isaac with a research grant.

\section{References}

Adams, P. B. (1980). Life history patterns in marine fishes and their consequences for management. Fishery Bulletin 78(1), 1-12

Aragão, J. A. N. (2012). Dinâmica populacional e avaliação do estoque do camarão rosa (Farfantepenaeus subtilis Pérez Farfante, 1967) na plataforma continental amazônica brasileira. [Tese de Doutorado]. São Carlos (SP): Escola de Engenharia de São Carlos da Universidade de São Paulo 
Aragão, J. A. N, Cintra, I. H. A, \& Silva, K. C. A. (2015a). Situação da pesca de camarões na plataforma continental amazônica. Acta of Fisheries Aquatic Ressources. 3(2),61-76. 10.2312/Actafish.2015.3.2.61-76

Aragão, J. A. N., Silva, K. C. A., \& Cintra, I. H. A. (2015b). Pesca Industrial do camarão-rosa na Plataforma Continental Amazônica: aspectos da dinâmica da população, avaliação do estoque e influência dos parâmetros ambientais. Acta of Fisheries Aquatic Ressources. 3(1), 77-90. 10.2312/Actafish.2015.3.1.77-90

Baker, R., M. Fujiwara, T.J. \& Minello. (2014). Juvenile growth and mortality effects on white shrimp Litopenaeus setiferus population dynamics in the northern Gulf of Mexico. Fisheries Research 155, 74-82. 10.1016/j.fishres.2014.02.026

Barthem, R. B. \& Schwassmann, H. O. (1994). The Amazon river influence over the seasonal displacement of the salty wedges in Tocantins estuary, Brazil, 1983-1985. Boletim do Museu Paraense Emílio Goeldi. 10(1):119-130. http://repositorio.museu-goeldi.br/handle/mgoeldi/496

Bentes, B., Mendes, N. C. B., Klautau, A. G. C. M., Viana, C. S., Romão-Junior, J. G., Silva, K. C. A. Andrade, C. E. R., Pereira, L. J. G., \& Cintra, I. H. A. (2019). Incidentaç catch of goliath grouper Epinephelus itajara (Lichtenstein, 1822) e Epinephelus sp. (Block, 1793) in industrial fisheries of Brazilian Nothern Coast: a critical endengerous species. Biota Amazônia. 9(1)58-59. 10.18561/2179-5746/biotaamazonia.v9n1p58-59

Bentes, B., Peixoto, U. I., Andrade, C. E. R., Maia, B. P., Giarrizzo, T., \& Cintra, I. H. A., (2020). Baseline and bycatch reduction devices test in marine shrimps' industrial fisheries of the North Coast. FAO technical papers (in press)

Betts, R. A., Malhi, Y., \& Roberts, J. T.: The Future Of The Amazon: New Perspectives From Climate, Ecosystem And Social Sciences, Philos. T. Roy. Soc. B, 363, 1729-1735. 10.1098/rstb.2008.0011

Blanchard, F, Chaboud, C, \& Thébaud, O. (2019). Back to the future: A retrospective assessment of model-based scenarios for the management of the shrimp fishery in French Guiana facing global change. Natural Resource Modeling. 32:e12232. 10.1111/nrm.12232

Brasil, 1980. (2020). Portaria SUDEPE no N-007 de 25 de fevereiro de 1980. https://www.icmbio.gov.br/cepsul/images/stories/legislacao/Portaria/198 0/p_sudepe_07_n_1980_limitabarcosarrastoparapescacamaraorosa_regiaonorte.pdf

Brasil, 2017. (2020). Portaria Interministerial n ${ }^{\circ} 75$, de 20 de dezembro de 2017. Retrieved from https://www.gov.br/agricultura/pt-br/assuntos/aquicultura-epesca/legislacao/defesos/portaria-interministerial-mdic-mma-no-75_12_2017.pdf/view

Brasil, 2018. (2020). Portaria Interministerial MDIC/MMA n 15 , de 10 de janeiro de 2018. https://www.gov.br/agricultura/pt-br/assuntos/aquicultura-epesca/legislacao/arrasto/portaria-mdic-mma-no-15-de-10-01-2018.pdf/view

Carvalho, R. C. A., Chaves, R. A., \& Cintra, I. H. A. (2003). Análise de custos e rentabilidade de embarcações industriais envolvidas na captura de camarãorosa no litoral Norte do Brasil, 2002. Boletim Técnico Científico CEPNOR, 3(1), 179-190. https://www.icmbio.gov.br/cepnor/images/stories/publicacoes/btc/vol03/art11-v03.pdf

Chemonics. 2002. Subsector assessment of the Nigerian shrimp and prawn industry. Chemonics International Inc., Agricultural Development Assistance in Nigeria. Washington, DC, United States, United States Agency for International Development.

Christensen, V. (1996).Virtual population reality. Reviews in Fish Biology and fisheries. 6, 243-247. 10.1007/BF00182345

Cintra, I. H. A., Aragão, J. A. N., \& Silva, K. C. A. Maturação gonadal do camarão-rosa, Farfantepenaeus subtilis (Pérez-Farfante, 1967), na região norte do Brasil. Boletim Técnico Cientifico do CEPNOR. Belém, 4 , 21-29

Conolly, P. C. (1992). Bycatch activities in Brazil. In: JONES, R. P. International Conference on Shrimp Bycatch. Lake Buena Vista, Florida. Sponsored by Southeastern Fisheries Association, Tallahassee. Session 5, 291-302. https://www.icmbio.gov.br/cepsul/images/stories/biblioteca/download/eventos_cie ntificos/e ve_1992_bycatch_ativities_brazil.pdf

Csirke, J., J. F., Caddy, J. F., \& Garcia, S. (1987) Methods of Size-Frequency Analysis and Their Incorporation in Programs for Fish Stock Assessment in Developing Countries. In: Pauly, D. and G.R. Morgan, editors. 1987. Length-based methods in fisheries research. ICLARM Conference Proceedings 13, 468 p. International Center for Living Aquatic Resources Management, Manila, Philippines, and Kuwait Institute for Scientific Research, Safat, Kuwai. http://pubs.iclarm.net/libinfo/Pdf/Pub\%20CP6\%2013.pdf

Dall, W., Hill, B. J., Rothlisberg, P. C., \& Sharple, D. J. (1990). The biology of the Penaeidae. Advances in Marine Biology, 27: 489pp.

Damasceno, F. G. \& Evangelista, J. E. V. 1991. Composição, estrutura e volume da fauna acompanhante da pesca industrial de camarão no litoral Norte do Brasil. Instituto Brasileiro do meio Ambiente e dos Recursos Naturais Renovaveis, IBAMA, Relatório Interno (MIMEO), Belém, 35p.

Davies, R. W. D., Cripps, S. J., Nickson, A., \& Porter, G. (2009). Defining and estimating global marine fisheries bycatch. Marine Policy, 33(4), 661-672. 10.1016/j.marpol.2009.01.003

Di Cintio, A. \& Luis, B. M. 2017. Potential for Eco-label Certification: the Case of the Campeche Shrimp Fishery, Mexico. Gulf and Caribbean Research 27:GCFI 7-22. http:/doi.org/10.18785/gcr.2801.11

Ehrhardt, N. M., Aragão, J. A. N. \& Silva, K. C. A. (1999). Stock assessment of the industrial pink shrimp (Penaeus subtilis) fishery in Northern Brazil. CFRAMP/FAO/DANIDA Stock Assessment Workshop on the Shrimp and Groundfish on the Guyana-Brasil Shelf, Port of Spain, Trinidad and Tobago. 99$111 \mathrm{p}$.

Ekau, W, \& Knopers, B. (1999). An introduction to the pelagic system of the North-East and East Brazilian shelf. Archive of Fishery and Marine Research. 47(2), 113-132. https://www.researchgate.net/publication/279695392_An_introduction_to_the_pelagic_system_of_the_North-East_and_East_Brazilian_shelf

Ferreira, L. M. L. (2012). Estrutura populacional e biologia reprodutiva de Farfantepenaeus subtilis (Perez-Farfante, 1967) capturado em pescarias industrias na costa norte do Brasil. Trabalho de conclusão de curso, Universidade Federal do Pará (UFPA). Campus Bragança. Brasil. 
Food and Agriculture Organization of the United Nations (2020). The State of World Fisheries and Aquaculture 2020. Sustainability in action. Rome, Italy. Retrieved from: http://www.fao.org/3/ca9229en/ca9229en.pdf

Food and Agriculture Organization of the United Nations (2017). Background documents for the Workshop on investing in ecosystem-based shrimp and groundfish fisheries management of the Guianas - Brazil shelf, Barbados, 7-8 September 2015. FAO Fisheries and Aquaculture Circular No. 1120. Rome, Italy. Retrieved from: http://www.fao.org/3/a-i5648e.pdf

Foster S. J., \& Vincent A. C. J. 2010. Tropical shrimp trawl fisheries: fishers' knowledge of and attitudes about a doomed fishery. Marine Policy. v34:437446. https://doi.org/10.1016/j.marpol.2009.09.010

Frédou, F. L., Mourão, K., Barbosa, C., Almeida, O., Rivero, S., Thompson, R. (2009) Caracterização das pescarias industriais da costa norte do Brasil. Paper do NAEA, 237, 1-33. Retrived from: http://www.naea.ufpa.br/naea/novosite/paper/149

García, S., (1988). Tropical penaeid prawns, in: Gulland, J.A. (Ed.), Fish population dynamics: the implications for management. Sydney, Australia, pp. 219249. Retrieved from: https://core.ac.uk/reader/39868106

Garcia S. M. (1996). Stock-recruitment relationships and the precautionary approach to management of tropical shrimp fisheries. Marine and Freshwater Research 47, 43-58. 10.1071/MF9960043

Gillett, R. (2008). Global study of shrimp fisheries. FAO Fish. Techn. Pap. No 475: Rome, FAO. 331p. Retrieved from: http://www.fao.org/3/a-i0300e.pdf Gulland, J. A., Rosenberg, A. A (1992). A review of length-based approaches to assessing fish stocks. FAO Fisheries Technical Paper. No. 323. Rome, Italy, 100p. Retrieved from: http://www.fao.org/3/t0535e/T0535E00.htm

Heileman, S., 2008. North Brazil shelf LME, pp. 701 e 710. In: Sherman, K., Hempel, G. (Eds.), The UNEP Large Marine Ecosystems Report: a Perspective on Changing Conditions in LMEs of the World's Regional Seas., United Nations Environment Programme. United Nations Environment Programme, pp. $701 \mathrm{e} 710$.

Hilborn, R., Amoroso, R. O., Anderson, C. M., Baum, J. K., Branch, T. A., Costello, C., \& Ye, Y. (2020). Effective fisheries management instrumental in improving fish stock status. Proceedings of the National Academy of Sciences, 117(4), 2218-2224. 10.1073/pnas.1909726116

Instituto Brasileiro do Meio Ambiente e dos Recursos Naturais Renováveis (1994). Camarão norte e piramutaba: relatórios reuniões dos grupos permanentes de estudos. IBAMA. Coleção Meio Ambiente, Brasília: Série Estudos-Pesca 9. Brasília: Ibama.

Instituto Brasileiro do Meio Ambiente e dos Recursos Naturais Renováveis (2007). Estatística da Pesca 2007: grandes regiõeses e unidades da Federação. IBAMA Brasília, Brazil.)

Isaac, V. J. \& Braga, M. T. (1999). Rejeição de pescado nas pescarias da Região Norte do Brasil. Arquivos de Ciências do Mar. Fortaleza, 32(1-2),39-54. 10.32360/acmar.v32i1-2.31342

Isaac, V. J., \& Ferrari, S. F., 2017. Assessment and management of the North Brazil Shelf Large Marine Ecosystem. Environmental Development. 22: 97-110. 10.1016/j.envdev.2016.11.004

Isaac, V. J., Dias Neto, J., \& Damasceno, F. G. (1992). Camarão-rosa da costa norte. Biologia, dinâmica e administração pesqueira. IBAMA, Série Estudos de Pesca, Brasília, 1: 1-187.

Isaac, V. J., Santo, R. V. E., Bentes, B., Frédou, F. L., Mourão, K. R. M., \& Frédou, T. (2009). An interdisciplinary evaluation of fishery production systems off the state of Pará in North Brazil. Journal of Applied Ichthyology. 25, 244-255. 10.1111/j.1439-0426.2009.01274.X

Jones R. \& Van Zalinge N. P. (1981). Estimates of mortality rate and population size for shrimp in Kuwait waters. Kuwait Bulletin on Marine Sciences . 2:273 $-288$

Jones, R. (1984). Assessing the effects of changes in the exploitation pattern using length composition data (with notes on VPA and cohort analysis). FAO Fisheries Technical Paper. 256, 118p.

Jones, J. B. (1992). Environmental impact of trawling on the seabed: A review. New Zealand Journal of Marine and Freshwater Research, 26(1), 59-67, $10.1080 / 00288330.1992 .9516500$

Lassen, H., \& Medley, P. (2001). Virtual population analysis - a practical manual for stock assessment. FAO Fisheries Technical Paper 138p. Retrieved from: http://www.fao.org/3/a-x9026e.pdf

MacCall, A. D. (2015). Changes in the biomass of California current ecosystem, pp 33-54, In: Variability and Management of Large Marine Ecosystems, pp 33-54 (K. Sherman and L. Alexander, Eds.). AAAS Selected Symposium 99, Boulder, CO: Westview Press.

Mace, M. M. \& Rozas, L. P. (2015). Estimating Natural Mortality Rates of Juvenile White Shrimp Litopenaeus setiferus . Estuaries and Coasts 38, 1580-1592 (2015). https://doi.org/10.1007/s12237-014-9901-7

Maia, B. P., Nunes, Z. M. P., Holanda, F. C. A. F., Silva, V. H. S., \& Bentes, B. (2016). Gradiente latitudinal da beta diversidade da fauna acompanhante das pescarias industriais de camarões marinhos da costa norte do Brasil. Biota Amazônia. 6(1), 31-39. 10.18561/2179-5746/biotaamazonia.v6n1p31-39

Marceniuk, A. P., Rotundo, M. M., Caires, R. A., Cordeiro, A. P. B., Wosiacki, W. B., Oliveira, C., Souza-Serra, R. R. M., Romão-Júnior, J. G., Santos, W. C. R., Reis, T. S., Muniz, M. R., Cardoso, G. S., Ferrari, S., Klautau, A. G. C. M., \& Montag, L. (2019). The bony fishes (Teleostei) caught by industrial trawlers off the Brazilian North coast, with insights into its conservation. Neotropical Ichthyology. 17(2), e180038. 10.1590/1982-0224-20180038

Martell, S. \& Froese, R. (2012). A simple method for estimating MSY from catch and resilience. Fish and Fisheries, 14(4), 504-514. 10.1111/j.14672979.2012.00485.x 
Martins, D. E. G., Camargo-Zorro, M. S. F., Walfir, P. M., Cintra, I. H. A., \& Silva, K. C. A. (2015). Spatial distribution of southern brown shrimp (Farfantepenaeus subtilis) on the Amazon continental shelf: a fishery, marine geology and GIS integrated approach. Brazilian Journal of Oceanography. 63(4), 397-406. 10.1590/S1679-87592015090106304

McConnaughey, R. A., Hiddink, J. G., Jennings, S., Pitcher, C. R., Kaiser, M. J., Suuronen, P. Sciberras, M. Rijnsdorp, A. D., Collie, J. S., Mazor, T. Amoroso, R. O., Parma, A. M., \& Hilborn, R. (2020). Choosing best practices for managing impacts of trawl fishing on seabed habitats and biota. Fish Fisheries, 21, 319- 337. 10.1111/faf.12431

Ministério da Pesca e Aquicultura - MPA, 2011. Boletim estatistico da pesca e aquicultura. 489 Brasilia, 60p. Retrivead from: https://www.icmbio.gov.br/cepsul/images/stories/biblioteca/download/estatistica/est_2011_bol_bra.pdf

Nagelkerken, I. Blaber, S. J. M., Bouillon, S., Green, P., Haywood, M., Kirton, L. G., Meynecke, J. O., Pawlik, J., Penrose, H. M., Sasekumar, A., \& Somerfield, P. J. (2008). The habitat function of mangroves for terrestrial and marine fauna: A review, Aquatic Botany, Volume 89, Issue 2, 2008, Pages 155$185,10.1016 /$ j.aquabot.2007.12.007

Nittrouer C. A., Kuehl, S. A., DeMaster, D. J., \& Kowsmann, R. (1986). The deltaic nature of Amazon shelf sedimentation. Geological Society of America Bulletin. 97, 444-458. 10.1130/0016-7606(1986)97<444:TDNOAS>2.0.CO,2

Nittrouer, A., \& DeMaster, D. J. (1996). The amazon shelf setting: tropical, energetic, and influenced by a large river. Continental Shelf Research.. 16, 553573. $10.1016 / 0278-4343(95) 00069-0$

Paiva, K. S., Aragão, J. A. N., Silva, K. C. A., \& Cintra, I. H. A. (2009). Fauna acompanhante da pesca industrial do camarão-rosa na plataforma continental norte brasileira. Boletim Técnico Científico do CEPNOR. 9(1), 25-42. 10.32519/tjfas.v9i1.778

Pauly, D. (1984). Fish population dynamics in tropical waters: a manual for use with programmable calculators. ICLARM (International Center for Living Aquatic Resources Management), Manila Philippines, Studies and Reviews 8, 325p. Retrieved from: https://s3-us-west2.amazonaws.com/legacy.seaaroundus/doc/Researcher+Publications/dpauly/PDF/1984/Books+and+Chapters/FishPopulationDynamicsTropicalWatersManual. pdf

Pauly, D. \& Ingles, J. (1986) The relationship between shrimp yields and intertidal (mangrove) areas: a reassessment. In: IOC:FAO Workshop on Recruitment in Tropical Coastal Demersal Communities. IOC, UNESCO, Paris, pp. 227-284.

Peixoto, et al., Mello-Filho, A. S., Bentes, B., \& Isaac, V. J. (2020) Migration pattern and size composition of southern brown shrimp (Penaeus subtilis Perez-Farfante 1967) caught on the Amazon Continental Shelf: Insights to management. Manuscript submitted.

Pérez-Castañeda, R., \& Defeo, O. (2002). Morphometric relationships of penaeid shrimps in a coastal lagoon: spatio-temporal variability and management

Pérez-Castañeda, R. \& Defeo, O. (2005). Growth and mortality of transient shrimp populations (Farfantepenaeus spp.) in a coastal lagoon of Mexico: role of the environment and density-dependence. ICES Journal of Marine Science. 62(1)14-24. 10.1016/j.icesjms.2004.10.005

Pérez Roda, M. A. (ed.), Gilman, E., Huntington, T., Kennelly, S.J., Suuronen, P., Chaloupka, M. and Medley, P. 2019. A third assessment of global marine fisheries discards. FAO Fisheries and Aquaculture Technical Paper No. 633. Rome, Italy. 78. Retrived from: http://www.fao.org/3/CA2905EN/ca2905en.pdf Pianka E. R. (1974). Evolutionary ecology. New York and Austin, TX: Harper and Row and University of Texas, 356 p.

Pilling, G., Apostolaki, P., Failler, P., Floros, C., Large, P.A., Morales-Nin, B., Reglero, P., Stergio, K. I., \& Tsikliras, A. C., 2008. Assessment and Management of Data-Poor Fisheries. Chapter 12. In: A Payne, J Cotter, T Potter. Editors. dvances in Fisheries science: 50 years on from Beverton and Holt. Publisher: Blackwell Publishing 10.1002/9781444302653.ch12

Quinn T. J., Deriso R. B. (1999) Quantitative fish dynamics. Oxford University Press.

Sanz, N., Diop, B., Blanchard, F., \& Lampert, L., 2016. On the influence of environmental factors on harvest: the French Guiana shrimp fishery paradox. Environmental Economics and Policy Studies, 19(2), 233-247. 10.1007/s10018-016-0153-6

Scarnecchia D. L., Lim, Y., Ryckman, L. F., Backes, M. K., Miller, S. E., Gangl, R. S, \& Schmitz, B. J. Virtual Population Analysis, Episodic Recruitment, and Harvest Management of Paddlefish with Applications to Other Acipenseriform Fishes. Reviews in Fisheries Science \& Aquaculture. 2014, 22(1):16-35. https://doi.org/10.1080/10641262.2013.830592

Sparre, P., \& Venema, S.C. Introdução à avaliação de mananciais de peixes tropicais. Parte 1 Manual. FAO Documento Técnico sobre as Pescas. No. 306/1, Rev.2. Roma, FAO. 1997. 404p.

Stiles, M. L., Stockbridge, J., Lande, M., \& Hirshfield, M. F. 2010. Impacts of Bottom Trawling on Fisheries, Tourism, and the Marine Environment. Oceana, $12 \mathrm{p}$.

Stobutzki, I. C., Miller, M. J., Jones, P., \& Salini, J. P. 2001. Bycatch diversity and variation in penaeid fisheries, the implications for monitoring. Fisheries Research. 53(3), 283-301. 10.1016/S0165-7836(00)00273-3

Tavares, C., \& Gusmão, J. (2016). Description of a new Penaeidae (Decapoda: Dendrobranchiata) species, Farfantepenaeus isabelae sp. nov. Zootaxa, 4171 (3), 505-516. 10.11646/zootaxa.4171.3.6

Thorpe, R. B. (2019). What is multispecies MSY? A worked example from the North Sea. Journal of Fish Biology. 94, 1011-1018. 10.1111/jfb.13967

Vetter, E. F. (1988). Estimation of natural mortality in fish stocks: A review. Fishery Bulletin 86: 25-43.

Wetherall, J.A., Polovina J. J., \& Ralston, S. (1987). Estimating Growth and Mortality in Steady-State Fish Stocks from Length-Frequency Data.p. 53-74. In: Pauly, D. and Morgan, G.R. 7. Length-based methods in fisheries research. ICLARM Conference Proceedings 13, 468 p. International Center for Living Aquatic Resources Management, Manila, Philippines, and Kuwait Institute for Scientific Research, Safat, Kuwait 